\title{
The Perception of Rural Households on Climate Change Effect on Rural Livelihoods in Lake Victoria Basin
}

\author{
Evans Odhiambo Wabwire ${ }^{1^{*}}$ \\ Stellah Mukhovi ${ }^{2}$ \\ Isaiah Ang'iro Nyandega ${ }^{2}$
}

\begin{abstract}
While the science of climate change is well investigated across most disciplines, people's perception of climate change effects has not been well addressed. This paper sought to address the question of climate change perception and the effect of climate change on rural household livelihoods within the Lake Victoria Basin of Kenya. The study relied on households' perception of effect of climate change on the areas of agriculture, and food security, water, and energy supply. Multistage sampling was applied to select 539 households from four eco-ecological zones. The study revealed that most households presented localized explanations of climate change, which included: frequent and prolonged droughts, variations in rainfall onset and cessation, increased temperatures, an increased strong wind episode. Some households perceived climate changes effects resulted into a decrease in crop yield, resulting in increased household food insecurity, while some perceived water stress at household level, but mainly for those who relied on surface water, well water, borehole, and the natural spring. In addition, some of the households perceived shortage in energy sources, particularly hydroelectric power was said to be sensitive to the changes in climate. These perceptions were based on households' experiences, and partially the results were found to be consistent with physical science of climate change. The paper therefore recommends the need to harmonise household perception with the climate change policy in order to address emerging challenges of climate change at the local level, create more climate change awareness supported through a comprehensive climate change action plan on country's preparedness of extreme climate events at household level.
\end{abstract}

Key words: Climate change, climate variability, Livelihoods, Lake Victoria Basin

${ }^{1}$ Catholic University of Eastern Africa, Department of Humanities, * Corresponding email; evacfx@yahoo.com, ewabwire@cuea.edu, ${ }^{2}$ University of Nairobi, Department of Geography and Environmental Studies

Ghana Journal of Geography Vol. 12 (2), 2020 pages 62- 83

https://dx.doi.org/10.4314/gjg.v12i2.3 


\section{Introduction}

Impacts of climate change on human society has extensively been discussed (Boko et al., 2018; IPCC, 2001b; IPCC, 2007). These reports have been categorical about high vulnerability in Africa owed to the people's low adaptive capacity. There is consensus that climate change will exacerbate a growing challenge on agriculture and further, disrupting food stability through alleviation of poverty (Thornton et al., 2009). Antwi-Agyei et al. (2013) established factors that contribute to household vulnerability to climate change in Ghana and factors such as overdependence of household on rainfed agriculture, lack of diversification on household income (Friedman et al., 2019), and limited access to reliable climate information. Changes in temperature and precipitation extremes are obvious in the East Africa region (Gebrechorkos et al., 2019), furthermore, Ambeje et al., (2011) reported climate extremes in some parts LVBK, attributing that to shortage in food supply, limited access to income and needed social services. El Nino related events are reported (Indeje et al., 2000) to cause changes in weather patterns in some parts of equatorial-subtropics of East Africa. The erratic weather patterns experienced within Africa from 1980 to 2000 tripled food crisis per year (FAO, 2004); while droughts diminished water supplies (Gan et al., 2016) and a decline in crop production, which resulted in rampant famine faced in Africa. For instance, in Kenya, a good proportion of the vulnerable population depends on climate-based resources, which are affected by frequent drought event (Tumushabe, 2018), and flooding which are some aspects of climate change.

Climate change, therefore, has a serious implication on the economy of many underdeveloped countries. With climate change projections showing more uncertainty, there is increased concern over its current and future impacts on vulnerable people (Xu et al., 2009). There are several factors contributing to high household vulnerability to climate change; these factors include poverty level, overreliance on natural resources, subsistence nature of their production, and limited adaptive capacity (Yaro, 2004; Pavola, 2008; Abdul-Razak and Kruse, 2017; Simotwo et al 2018). However, many households employ different adaptation strategies to cushion themselves against risks (Burney et al 2014; Belay et al. 2017). Households' adaptation, however, depends on each household's perception of climate change risks to their livelihoods (Jarawura, 2014).

Livelihoods are described as peoples' capabilities, assets, and activities that are required to make a living (Turner et al. 2015). According to Bebbington (as cited in King, 2012), livelihoods assets are physical, natural, human, financial, and social-cultural in nature. Sustainable livelihoods are achieved when households have access to household resources that are combined in pursuit of different 
The Perception of Rural Households on Climate Change Effect on Rural Livelihoods in Lake Victoria Basin

livelihood strategies (Asravor, 2018; Scoones, 1998). It also must also protect the natural resource base without which the livelihoods would be jeopardized.

\section{Literature review and theoretical background}

\section{Literature Review}

The majority of rural households in Sub-Saharan Africa depend on rainfed farming, which is susceptible to changes in climate (Keshavarz et al., 2017; Mikalitsa, 2010; Amissah, 2003; Spence et al., 2011; Cooper et al., 2008). It is estimated that one-third of Africa's population lives in droughtprone areas and, that poverty levels have risen in the recent past (Beegle \& Christiaensen, 2019) with number likely to go even higher to extreme climate exposure. A study on the effect of climate change on small scale farmers in Tanzania, revealed a $3.3 \%$ decrease in food production due to the decade decrease in rainfall (Mbilinyi et al., 2013). This resulted in a corresponding increase in food insecurity in the country. In Lake Victoria basin, frequent and severe drought e, which is linked to climate change, has been observed (Awange et al 2007). Wabwire et al. (2020) recorded changes in onset and cessation of both short and long rains because of climate change which was likely to escalate rural livelihood challenges. A study by Mertz et al. (2009), asserted that the frequency and severity of such climate events had the capability of causing a decline in the number of livestock, especially in their drier areas and result into a drop in crop yield in arable lands (Weber, 2010). The livelihood activities of most of households have directly or indirectly been affected by climate events (Le Dang et al., 2014; Ambeje et al. 2011; Akudugu et al., 2013). Changes in the rainfall onsets, prolonged and intensified droughts, threaten food security (Herrera et al., 2018; FAO 2009), increase water stress (FAO, WFP, and IFAD, 2010) and exacerbate poverty level in the region (Hiscock \& Tanaka, 2006).

Gendered Climate change study by Mainlay and Tan (2012) revealed that climate change exposed more women to high vulnerability than men due to their gender roles. Incidents of drought for instance, contributed to water stress, which forced women to search for alternative sources at distant places (Lama, 2010). Water shortage hits hard on woman's routine, as they have to cope with the domestic and kitchen, compromising girls' useful time on schooling and well-being. Additionally, Karki et al. (2017) in their study asserted that scarcity of water supply affected menstrual cleanliness among adolescent girls particularly in poor societies.

A study by Davis et al. (2018) indicated that when the climate variability and change become extreme, people would migrate to areas where they perceived have a favourable climate. Migration could likely lead to congestion in an area resulting in unemployment and poor health services. Extreme climate 
also increases morbidity and mortality because most people will not be in a position to access basic needs because of limited income triggered by employment (Kjellstrom et al. 2020; Riley et al. 2018).

A study by Clement (as cited by Tirado \& Meerman, 2012) on climate change and human health concluded that changes in climate modified the transmission of diseases such as cholera, malaria and meningitis. The modelling of climate change and malaria transmission dynamics further revealed that extreme weather conditions triggered more malaria cases in Kenya (Eikenberry \& Gumel, 2018).

The vulnerability of the coastal communities cannot be overemphasized. There is a change in altered ocean currents to salinity intrusion, from heavy and erratic rainfall to flash floods. This situation has forced some people to search for other means of livelihood (Cinner et al. 2012), for some households whose livelihoods is agro-ecologically dictated they have had to integrate other activities to supplement agriculture since it's no longer dependable (Dube et al. 2016). Extreme climate events have forced people to migrate from their homes in search of a means of survival. Such changes in climate are not only a major global environmental challenge but also a problem of great concern in third world countries. Most households in Africa are likely to find themselves victims of such problems, which have a direct impact on the livelihood strategies. In the Northern Hemisphere, climate change is said to have increased global average surface temperature, resulting into sea levels rise and a decrease in snow cover (Brown \& Mote 2009).

While much attention has been focused on science of climate change, people's perception of climate change has not received same attention. The available literature has demonstrated the effects of climate change, showing its impact on food security, water and energy supply. These studies have however, not been candid on households' perception of climate change effects on livelihood sources and activities. It is in this context that this study sought to bridge the existing gap in literature on household's perception of climate change and its effects on the livelihood.

\section{Theoretical Background}

The study is based on the Sustainable Livelihood Approach (SLA) framework. The framework arose during the early 1990s (Hope \& Kempe, 2009). SLA is a reaction to changes in general thinking about development as top-down processes, to one that is centered more on the participation of local communities (Solebury, 2003). Sustainable Livelihood Framework provides the key components that make up a livelihood and the contextual factors that support them. These factors include the five capitals (human, social, natural, financial, and physical) (Reed et al., 2013). Other capitals have been 
documented such as information (Odero, 2008), and cultural and institutional assets (Cochrane, 2006). Climate change has the potential of affecting livelihood activities, key natural resources, and infrastructure critical for livelihood.

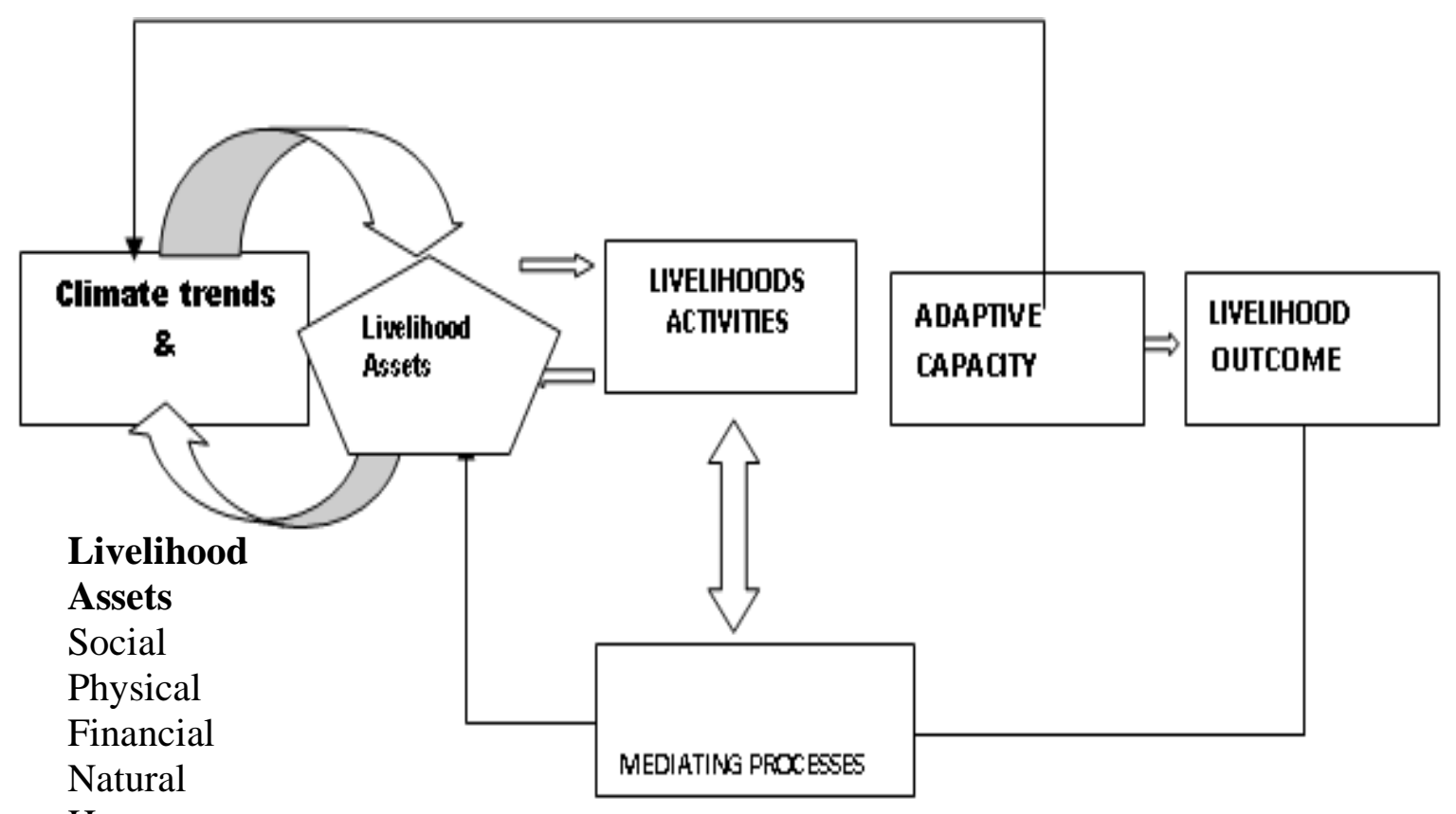

Human

Figure 1. Modified Sustainable Livelihood Framework

Source: DFID (2000)

The notion of sustainable livelihood, (Figure 1), seeks to reinforce human's ability to manage and recuperate from challenges unleashed by climate change while, at the same time enhancing its capabilities, assets, and activities both now and in the future, without undermining the natural resource base (Chambers \& Conway, 1992). The approach is noted to have several strengths in assessing livelihood indicators that relate to the study (DFID, 2000). The SLA is people-centered and therefore, centers on people as opposed to the resources they use in earning their livelihood. The approach lays a strong emphasis on the role of the poor and vulnerable such as rural households. The dynamic nature of this approach in determining the impact of climate change and the livelihood outcomes that shape the household's life have extensively been explored (Reed et al. 2013). Few limitations have been noted with this approach and of them is the fact that it does not emphasize the need to identify each individual's household needs and problems (Farrington et al., 1999), and also, it oversimplifies household livelihoods realities (Brocklesby \& Fisher, 2003). Despite its limitation, this approach was best suited for this study since it helped in the identifying the underlying strengths of each household to navigate through the effects of climate change, and prioritize actions for each vulnerable household. The SLA further enabled this study to make connections between people and their enabling environment that influenced the household livelihood outcomes. The approach has been applied to other studies in measuring livelihood resilience (Quandt, 2018), poverty reduction 
(Sati \& Vangchhia, 2016), and understanding poverty and vulnerability in communities (Gee Nee \& Mansur, 2015).

\section{Materials and Methods}

\section{Study Area}

The basin is situated between latitudes $1^{\circ} 15^{\prime}$ North and $1^{\circ} 30^{\prime}$ South and longitudes $34^{\circ}$ East and $35^{\circ} 30^{\prime}$ East. Consequently, its position makes it to experience a modified equatorial climate. The basin is an extensive geographical land extending from Mau ranges to the border of Uganda and Tanzania (Figure 2). It covers a total area of about $38,913 \mathrm{~km}^{2}$ which is about $21.5 \%$ of the overall basin, with a coastline of approximately $550 \mathrm{~km}$ (UNEP, 2002). The basin has a diverse landscape pattern, with the plains bordering the lake experiencing annual floods. The plains typically slope toward the lake and are surrounded by several hills, escarpments close to the valley and Mt. Elgon. The altitude ranges between 1800 to 3000 meters ASL, which typically affect the rainfall, and the temperature of the basin. The general location of the basin exposes the residents to yearly flood risks inflicting major destruction on their livelihoods.

The basin has a variety of climates, which range from a modified equatorial situated around the lake locality, to semi-arid situated within the lake literal. The modified equatorial climate is hot and humid, with significant rainfall occurring throughout the year, while the semi-arid type of climate is characterized by sporadic droughts.

The rainfall patterns follow the ITCZ movement; consequently, the bimodal rainfall is experienced from March to May, which is the period of the wettest months, while November to December experiences short rains. Annual rainfall varies between 700-2000mm (Figure 3.2). Rains are poorly distributed in the areas bordering the lake whereas highland areas receive high rainfall. In most areas, maximum and minimum temperature ranges between $28.6^{\circ} \mathrm{C}$ and $28.7^{\circ} \mathrm{C}$, and $14.7^{\circ} \mathrm{C}$ to $18.2^{\circ} \mathrm{C}$ respectively.

The population is about 13 million people with a higher population density of about 257 persons per square kilometers and, average population growth of 3\% (Government of Kenya, 2019). Agriculture is the dominant economic activity that sustains rural livelihoods in the basin. Crop farming is done alongside with livestock rearing as a buffer to crop failure. Major food crops grown under subsistence farming include; maize, millet, sorghum, cassava, beans, rice, potatoes, and groundnuts while main cash crops include; sugarcane, tea, coffee, and cotton. Most farming is rainfed and therefore very susceptible to climate change impacts. 

Basin

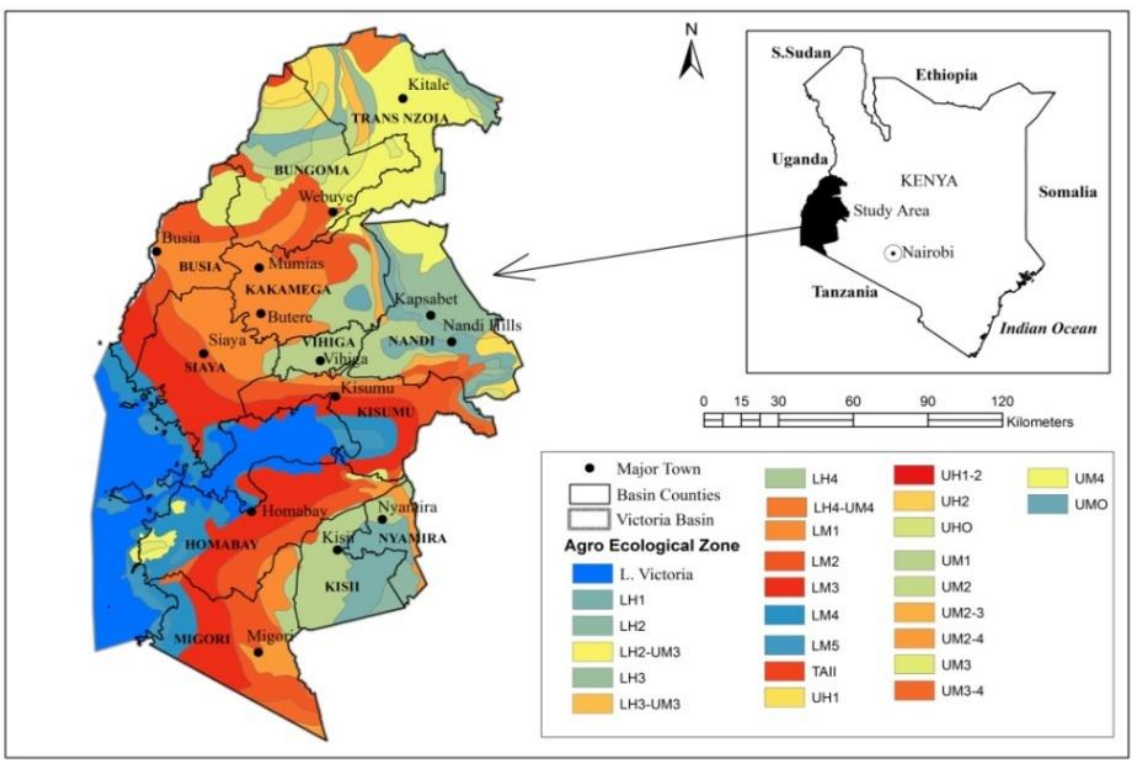

Figure 2: The Lake Victoria Basin of Kenya Source: Adopted from Kenya Soil Survey, 2017

\section{Methods}

This study was based on both qualitative and quantitative methods where data was collected from a stratified sample survey of 539 households. From the main agro-ecological zones of the Lake Victoria Basin of Kenya. The households were from Mururu, Tambua, Kibingei, and Chepchoina administrative wards, which represented the lower midland; the upper midland, lower highland, and upper highland agro ecological zone respectively (Table 1). The households selected for this study were rural in nature and their livelihood activities depended on climate-controlled resources. The target population of this study was smallholder farmers practicing rainfed agriculture. A multi-stage sampling stratified random sampling was used to select 539 households from four main agro-climatic zones in the Lake Victoria Basin of Kenya (Table 1). The population was stratified according to agroecological zones.

Table 1: Distribution of Selected Households from Study Site

\begin{tabular}{lllll}
\hline Agro-ecological zone & $\begin{array}{l}\text { Administrative } \\
\text { Ward }\end{array}$ & $\begin{array}{l}\text { Ward } \\
\text { Population }\end{array}$ & $\begin{array}{l}\text { Location } \\
\text { population }\end{array}$ & $\begin{array}{l}\text { No. of Selected } \\
\text { Households }\end{array}$ \\
\hline Lower Midland Zone & Muhuru & 4,669 & 1,320 & 132 \\
Upper midland zone & Tambua & 4,007 & 1,253 & 125 \\
Lower Highland zone & Kibingei & 6,460 & 1,639 & 163 \\
Upper Highland zone & Chepchoina & 1,865 & 1,195 & 119 \\
& Total & $\mathbf{1 7 , 0 0 1}$ & $\mathbf{5 , 4 0 7}$ & $\mathbf{5 3 9}$ \\
\hline
\end{tabular}

Government of Kenya. (2019)

The households were considered based on spatial representation and household rural livelihood characteristics. A questionnaire and interview schedule were administered to household heads by the 
researcher and a team of trained field assistants. The questionnaire was written in English however where respondents were illiterate, local translators were used. The collected data was analyzed quantitatively and qualitatively. All the statistics were performed using SPSS -IBM version 23

\section{Results}

\section{Rural Households' Perception of Climate Change Effect}

The study finding indicated that the majority of the households (96\%) perceived climate changes in the region. The result in Table 2 revealed that climate change perceived by the respondents include frequent and prolonged drought (42\%), variation in rainfall onset and cessations (12\%), increase heavy rains $(11 \%)$, and $9 \%$ of the household respondent perceived hailstones as part of climate changes. Other households' respondents perceived an increase in strong wind episodes (6\%), excessive rainfall in the region (6\%), and an increase in temperature (4\%). Based on agro-ecological zones, this study showed that the Lower Midland Zone had the highest number of households that perceived frequent and prolonged dry spells (42\%), while, Lower Highland zone had the highest number of households that perceived increased hailstone incidences (37\%). Increased strong wind episodes $(65 \%$, El Niño episode (45\%), and increased temperature $(65 \%)$ were also perceived by farmers. The Upper Highland zone had the highest number of households who perceived variation in rainfall onset and cessation (49\%) and an increase in heavy rain patterns (44\%). The study further revealed that a significant number of respondents from Upper Highland zone and Lower Highland zone perceived variation in rainfall onsets and cessations (49\%) and increase in temperature (65\%) respectively (Table 2 ). 
The Perception of Rural Households on Climate Change Effect on Rural Livelihoods in Lake Victoria Basin

Table 2. Household's perception of climate changes in the Lake Victoria Basin of Kenya.

\begin{tabular}{|c|c|c|c|c|c|}
\hline Climate change perception & $\begin{array}{l}\text { Upper } \\
\text { midland } \\
\text { zone } \\
\end{array}$ & $\begin{array}{l}\text { Lower } \\
\text { Midland } \\
\text { Zone }\end{array}$ & $\begin{array}{l}\text { Lower } \\
\text { Highland } \\
\text { zone }\end{array}$ & $\begin{array}{l}\text { Upper } \\
\text { Highland } \\
\text { zone }\end{array}$ & $\begin{array}{l}\text { Total/ } \\
\text { Percent }(\%)\end{array}$ \\
\hline $\begin{array}{l}\text { Frequent and prolonged dry } \\
\text { spells }\end{array}$ & $58(30 \%)$ & $82(42 \%)$ & $35(18 \%)$ & $22(11 \%)$ & $197(42 \%)$ \\
\hline $\begin{array}{l}\text { Variation in rainfall onset and } \\
\text { Cessation }\end{array}$ & $8(14 \%)$ & $6(11 \%)$ & $15(26 \%)$ & $28(49 \%)$ & $57(12 \%)$ \\
\hline Increase heavy rains & $10(19 \%)$ & $3(6 \%)$ & $17(32 \%)$ & $24(44 \%)$ & $54(11 \%)$ \\
\hline Increased hailstone incidence & $15(35 \%)$ & $7(16 \%)$ & $16(37 \%)$ & $5(12 \%)$ & $43(9 \%)$ \\
\hline $\begin{array}{l}\text { The increased outbreak of crop } \\
\text { pests and diseases }\end{array}$ & $3(8 \%)$ & $8(21 \%)$ & $18(46 \%)$ & $10(26 \%)$ & $39(8 \%)$ \\
\hline Increased Strong wind episodes & $8(24 \%)$ & $1(3 \%)$ & $22(65 \%)$ & $3(9 \%)$ & $34(7 \%)$ \\
\hline Excessive rainfall & $9(31 \%)$ & $4(14 \%)$ & $13(45 \%)$ & $3(10 \%)$ & $29(6 \%)$ \\
\hline Increased temperatures & $0(0 \%)$ & $3(15 \%)$ & $13(65 \%)$ & $4(20 \%)$ & $20(4 \%)$ \\
\hline Total & $111(24 \%)$ & $114(24 \%$ & $149(32 \%$ & $99(21 \%)$ & $473(100 \%)$ \\
\hline
\end{tabular}

Source: Researcher 2019

\section{Perception of Rural Households on Climate Change Effects on Livelihood Activities}

The study findings revealed a diversity in the livelihood activities, which included, farming, livestock rearing, trade, salaried work, and fishing, that contribute immensely to household provisioning in the Lake Victoria Basin. In addressing the question as to whether these livelihood activities are affected by the climate change effects, the study revealed that farming (40.2\%) is highly affected since it was ranked first among others. This was followed by livestock keeping (22.7\%) trade (21.4\%) and, salaried work (12.3\%) (Table 3). A small fraction of household respondents, mainly from Lower Midland Zone that is close to the Lake Victoria, perceived climate change effect on fishing (3.4\%). The lower midland zone is land that is more semi-arid had farming and livestock keeping least affected. In the upper highland zone, trade was the least affected by the climate change effect.

Table 3: Livelihood activities Affected by Climate Change at selected Agro-ecological Zone

\begin{tabular}{lllllll}
\hline $\begin{array}{l}\text { Livelihood } \\
\text { activities affected } \\
\text { by climate Change }\end{array}$ & $\begin{array}{l}\text { Upper } \\
\text { midland } \\
\text { zone }\end{array}$ & $\begin{array}{l}\text { Lower } \\
\text { Midland } \\
\text { Zone }\end{array}$ & $\begin{array}{l}\text { Lower } \\
\text { Highland } \\
\text { zone }\end{array}$ & $\begin{array}{l}\text { Upper } \\
\text { Highland } \\
\text { zone }\end{array}$ & Total & Rank \\
\hline Farming & $135(44.6 \%)$ & $30(21.3 \%)$ & $149(40.1 \%)$ & $103(46.0 \%)$ & $417(40.2 \%)$ & 1 \\
Livestock keeping & $93(30.7 \%)$ & $18(12.8 \%)$ & $39(10.5 \%)$ & $85(37.9 \%)$ & $23522.7 \%)$ & 2 \\
Trade & $38(12.5 \%)$ & $47(33.3 \%)$ & $130(34.9 \%)$ & $7(3.1 \%)$ & $222(21.4 \%)$ & 3 \\
Salaried Work & $32(10.6 \%)$ & $19(13.5 \%)$ & $50(13.4 \%)$ & $29(12.9 \%)$ & $127(12.3 \%)$ & 4 \\
Fishing & $5(1.7 \%)$ & $27(19.1 \%)$ & $4(1.1 \%)$ & $0(0 \%)$ & $36(3.4 \%)$ & 5 \\
& & & & & &
\end{tabular}

Source: Researcher 2019 


\section{Perception of Climate Change Effect on Agriculture and Household Food Security}

The respondents also suggested a decrease in crop yield from subsistence farming. About $47 \%$ of the respondents indicated that the crop yield had decreased, while still, other respondents argued that their crop production had increased a little (23\%). Some fewer respondents indicated that crop yield had increased by (6\%). The factors attributed to decrease in crop yield included pest infestation, change in rainfall patterns that affected the onsets and cessation of both long and short rainy seasons, unreliable rainfall. The unpredictable nature of rainfall pattern often results into little during planting and germination and too much rain during harvesting season. In the case of the latter, the crop often rots in the field. In cases where an increase in crop yield was observed, it was established that households had increased the use of farm inputs such as the use of hybrid seeds, fertilizers, and pesticides under the program rolled out in the area by One Acre Fund Project. Still, some households had moved to extensive farming.

The climate change effect on food security is not only complex but also difficult to discern. This is because food security is generally influenced by many other factors which might not be climate oriented. Perhaps climate change can only exacerbate food security due to its wider scope of effects. The study finding revealed $68 \%$ ) of the household respondents perceived climate change affected household food security while, $30 \%$ of the respondents perceived that climate change did not affect food security, $2 \%$ of the respondents were not sure.

\section{Perceived Climate Change Effect on Energy Sources}

Energy sources are vital in meeting the household livelihood need for lighting and heating. In rural areas, biomass comprises a major energy source; others include electricity and solar voltaic energy. Any potential stress in these commodities is likely to have an adverse effect. The finding of this study revealed a significant number of respondents $(69.5 \%)$ who were of the opinion that climate change has effect on household energy supply while fewer respondents $(30.5 \%)$ perceived that climate change had no effects energy supply source. The study established that household energy supply that was stressed because of climate change was hydroelectric energy (18.4\%), which was purely climate controlled, seasonal variations of rivers had led to power rationing; Kerosene (31.4\%), and charcoal $(1.8 \%)$ the prices had substantially increased; firewood (17.9\%) has limited the access (Table 4$)$. The $30.5 \%$ of respondents, who perceived no effect of climate change on household energy supply, indicated that increased awareness of climate change has increased household solar power harnessing as a way of adapting to changes. 
The Perception of Rural Households on Climate Change Effect on Rural Livelihoods in Lake Victoria Basin

Table 4. Perceived Climate Change Effect on Household Energy Resources in the Lake Victoria Basin of Kenya

\begin{tabular}{|c|c|c|c|c|c|}
\hline \multirow[t]{2}{*}{ County } & Positive Effect & \multicolumn{4}{|l|}{ Negative Effect } \\
\hline & Solar Voltaic & Charcoal & Electricity & Kerosene & Firewood \\
\hline $\begin{array}{l}\text { Upper midland } \\
\text { zone }\end{array}$ & $25(10.8 \%)$ & $0(0.0 \%)$ & $88(37.9 \%)$ & $52(22.4 \%)$ & $67(28.9 \%)$ \\
\hline $\begin{array}{l}\text { Lower Midland } \\
\text { Zone }\end{array}$ & $93(71.5 \%)$ & $2(1.5 \%)$ & $9(6.9 \%)$ & $26(20.0 \%)$ & $0(0.0 \%)$ \\
\hline $\begin{array}{l}\text { Lower Highland } \\
\text { zone }\end{array}$ & $116(32.0 \%)$ & $15(4.1 \%)$ & $67(18.5 \%)$ & $169(46.7 \%)$ & $97(26.8 \%)$ \\
\hline $\begin{array}{l}\text { Upper Highland } \\
\text { zone }\end{array}$ & $52(46.8 \%)$ & $0(0.0 \%)$ & $8(7.2 \%)$ & $47(42.3 \%)$ & $4(3.6 \%)$ \\
\hline Total & $286(30.5 \%)$ & $17(1.8 \%)$ & $172(18.4 \%)$ & $294(31.4 \%)$ & $168(17.9 \%)$ \\
\hline
\end{tabular}

Source: Researcher 2017

\section{Perceived Climate Change Effect on Household Water supply}

Water resources in the Lake Victoria Basin are controlled by climate. The study established households perceived that climate change effect in the Lake Victoria Basin, contributed to water supply from surface water by $36.6 \%$, for households whose main water supply was from rivers and streams were the most affected household water source. Well water (18.8\%), borehole (21\%), piped water $(11.4 \%)$, and the natural spring $(9.9 \%)$, and rain-harvested water $(2.4 \%)$ were another household water source that ware affected (Table 5).

Despite the variety of water sources in Lake Victoria Basin of Kenya, most households still experience water stress, which is exacerbated by frequent droughts experienced in the region. Most water sources tend to dry up earlier before another rainy season.

Table 5: Perceived Climate Change Effect on Water Sources in the Lake Victoria Basin of Kenya

\begin{tabular}{|c|c|c|c|c|c|c|}
\hline Water Source & $\begin{array}{l}\text { Upper } \\
\text { midland } \\
\text { zone }\end{array}$ & $\begin{array}{l}\text { Lower } \\
\text { Midland } \\
\text { Zone }\end{array}$ & $\begin{array}{l}\text { Lower } \\
\text { Highland } \\
\text { zone }\end{array}$ & $\begin{array}{l}\text { Upper } \\
\text { Highland zone }\end{array}$ & Total & Rank \\
\hline $\begin{array}{l}\text { Surface water- } \\
\text { Rivers/ Streams }\end{array}$ & $22(15.2 \%)$ & $104(78.2 \%)$ & $152(33.9 \%$ & $41(28.1 \%)$ & $319(36.6 \%)$ & 1 \\
\hline $\begin{array}{l}\text { Sub-surface } \\
\text { water-Well }\end{array}$ & $12(8.3 \%)$ & $3(2.3 \%)$ & $111(24.8 \%$ & $38(26.0 \%)$ & $164(18.8 \%)$ & 2 \\
\hline $\begin{array}{l}\text { Sub-surface } \\
\text { Borehole /pump }\end{array}$ & $19(13.1 \%)$ & $14(10.5 \%)$ & $90(20.1 \%)$ & $60(41.1 \%)$ & $183(21 \%)$ & 3 \\
\hline Piped water & $28(19.3 \%)$ & $7(5.3 \%)$ & $57(12.7 \%)$ & $7(4.8 \%)$ & $99(11.4 \%)$ & 4 \\
\hline Natural Spring & $47(32.4 \%)$ & $4(3.0 \%)$ & $35(7.8 \%)$ & $0(0.0 \%)$ & $86(9.9 \%)$ & 5 \\
\hline $\begin{array}{l}\text { Rain harvested } \\
\text { water }\end{array}$ & $17(11.7 \%)$ & $1(0.8 \%)$ & $3(0.7 \%)$ & $0(0.0 \%)$ & $21(2.4 \%)$ & 6 \\
\hline
\end{tabular}

Source: Researcher 2017 


\section{Discussions}

It was notable that the perception of households on climate change effects and adaptation strategies are shaped by many household's underlying factors (Poudel et al., 2017). In this study, households with formal education were more informed of climate change, which was also observed in El Salvador and Brazil where schooling played an increasing role in the communities' adaptive capacity (Wamsler et al., 2012). The majority of rural household heads in the Lake Victoria Basin of Kenya perceived significant changes in climate, which affected their livelihoods. The present study's findings resonate with earlier findings on the spatial and temporal characteristics of rainfall, which established variation in rainfall onsets and cessations, and frequent droughts in the recent past (Wabwire et al., 2020). Climate change continues to manifest its effects among the local poor affecting their household income, increasing food insecurity and vulnerability (Khisa et al., 2014), contrary to sustainable livelihoods for rural poor postulated in sustainable livelihood approach (Scoones, 2015).

While the science of climate change is well articulated in the existing literature (IPCC, 2007; IPCC 2001; Field, 2014), a study by Eastin (2018) revealed that there is no sufficient knowledge on climate change effect in developing countries. Eastin's (2018) study shows that climate change continues to be a pressing issue among many rural households. This study affirms earlier study by Deressa et al. (2011) who established several factors that shaped households' perception of climate change. Consequently, no single factor such as poverty could be attributed to how they view the effects of climate change on their livelihood. It further confirmed a consistent view that climate change affects gender roles performed at household level (Djouudi et al., 2016; Arora-Johsson, 2011). Eastin's (2008) study on climate change and gender equality in developing countries further alluded to the fact that the existence of gender disparities in climate change vulnerability was a clear mirror reflection of gender inequality in many developing states.

In Africa for instance, Deressa et al. (2011) established that while there exist inequalities in the ownership and control in household assets with the male being advantaged, women still play a crucial gender role in ensuring that most livelihood needs are met. Climate change effects increased stress on food and water access that further undermine women's capacity to achieve economic freedom, improve human capital, and preserve health welling being. Marital status is an important social factor that determines household livelihood. Panthi et al. (2016) asserted that marital status determines the family size. Tucker et al. (2015) established that marital status had a direct link with the social demographic characteristics of a household, increased rural household population for instance, was likely to increase vulnerability to climate change. Nabikolo et al. (2012) on the other hand affirmed that gender parities in climate change hampered women's opportunities to access land and credit 
The Perception of Rural Households on Climate Change Effect on Rural Livelihoods in Lake Victoria Basin

facilities. While Alam et al. (2015) and (Kristjanson et al., 2017) further concurred with the fact that women and males suffer disproportionately due to their place in society. The study findings, however, revealed that marital status did not affect the household perception of climate change effects.

The study suggested that poor households especially those that depend on small-scale agriculture are more vulnerable to negative effects of climate change (Berman et al., 2015). Households have adopted several responses to cope with the potential climate changes; however, not every response by the household to climate change offers a decent household livelihood (Eriksen et al., 2001). The rural household, therefore, involved in more activities such as; small business, agricultural productivity, and fishing to minimize the effect. These activities are all sensitive to climate changes hence increased household vulnerability.

The results of this study, however, seem to suggest the diversification of family sources of income as a vital role in households' adaptation to climate change. Lake Victoria where much of household livelihood activities depend on rainfed agriculture, high climate risks have been observed. The finding has also shown that rural household's economies, where credit facilities are minimal, have further diversified livelihoods activities which are less sensitive to changes in climate.

Shepardson et al. (2012) on the other hand concluded that there is still much that needs to be done to address the interface of the science of climate change and society as a means to inform future climate researchers. The IPCC (2014) Report indicated that climate change has a direct effect on sectors that are climate dependent and, further hampered by poverty. The effects of changes in climate cannot be overemphasized (Payne et al., 2004; IPCC, 2007; IPCC, 2014). Shobha et al. (2017) reiterate that the effect of climate change is exacerbated by poverty since the people living in developing areas have a low adaptive capacity

The study findings seem to agree with earlier studies by Arnell et al. (2002). The mentioned studies established the correlation between climate change and crop yield. Kotir (2011) observed climate change and its potential future pathways are likely to reduce agriculturally suitable areas, vary the length of growing seasons, and reduce the potential crop yield. Furthermore, IPCC (2014) affirmed that changes in climate are projected to reduce crop production, thus causing stress in food security. While it is true that climate change affects crop yield, its effect on food security is not only complex but also difficult to discern. A study by Thompson et al. (2010) alluded three aspects of food security that are highly impacted by climate change, which include availability, access, and utilization.

FAO (2009) examined food security as a condition where the entire human population, at all time, have sufficient access, safe, and nutritious food that meet dietary needs and preferences wellbeing. The household food security is indirectly or directly jeopardized by climate change (Oluoko-Odingo, 
2011). The food security is affected directly when weather elements such as rainfall variability affect crop productivity and indirectly when the food prices go up and household food access is comprised.

\section{Conclusion}

The findings of this study demonstrate that rural household in Lake Victoria Basin of Kenya is driven by climate base resources. The observed climatic change in the basin, which is manifested through frequent and prolonged droughts, variation in rainfall onset and cessation, heavy rains, increased hailstone incidences, an increased outbreak of crop pest and diseases, increased strong wind episodes and increased temperature pose challenges to most household livelihood activities

Climate change, for instance, has been observed to affect crop production within the basin, which, heavily relies on rainfed agriculture. Household food security is always at stake despite efforts to diversify the crops. In addition, household energy source has been affected through power rationing, altering fuel prices despite an increase in demand. On other hand, households have taken the advantages of power shortages to harness solar voltaic energy as away meeting their demand for energy and coping with energy shortages. The main water sources in the Lake Victoria Basin especially the surface water, which includes rivers and streams were the most affected household water source in both dry periods and a wet period when floods contaminate most water points accessible to the households.

To promote sustainable rural livelihoods, there is a need for policy interventions that address emerging climate change challenges with a special attention on rural households. Consequently, Climate Change Policy on education, research, and economic development needs to provide timely and credible climate change information that is household targeted. The government policy interventions should also ensure targeted household training on climate-smart agriculture, Integrated Water Use and Management and, Sustainable Rural Livelihood Strategies. Such government policy interventions will ensure that effective household adaptation strategies are adopted at the household level. There is a need for effective project investment policy not only at local and national governments but also at rural households' level to ensure that rural household livelihood sources are diversified to reduce further household vulnerability to climate change. 
The Perception of Rural Households on Climate Change Effect on Rural Livelihoods in Lake Victoria Basin

\section{Acknowledgements}

We would like to appreciate the households that participated in the study and the anonymous reviewers for their valuable comments.

\section{References}

Abdul-Razak, M., \& Kruse, S. (2017). The adaptive capacity of smallholder farmers to climate change in the Northern Region of Ghana. Climate Risk Management, 17, 104-122. https://doi.org/10.1016/j.crm.2017.06.001.

Akudugu, M. A.; Dittoh, S. and Mahama, E. S. (2012). The implications of climate change on food security and rural livelihoods: Experiences from Northern Ghana. Journal of Environment and Earth Science 2, no. 3, 21-29.

Alam, M., Bhatia, R., Mawby, B. (2015). Women and Climate Change. Impact and Agency in Human Rights, Security, and Economic Development. Georgetown Institute for Women, Peace and Security. $\quad$ https://www.climateinvestmentfunds.org/sites/default/files/knowledgedocuments/georgetown_women_and_climate_change 2015.pdf. Accessed on $10^{\text {th }}$ January 2020.

Ambeje, P., Marigi, S., Omeny, J, Njogu, A. and Kilavi, M. (2011). Trends in Rainfall and Temperature in Homa Bay and Busia Counties. Adaptation to Climate Change and Insurance Report, Kenya Meteorological Department, Nairobi, Kenya.

Amissah-A. A. (2003). Targeting climate forecasts for agricultural applications in sub-Saharan Africa: situating farmers in user-space. Climatic Change 58, no. 1-2 (2003): 73-92. https://doi.org/10.1023/A:1023462613213.

Arab, A., Jackson, M. C., \& Kongoli, C. (2014). Modelling the effects of weather and climate on malaria distributions in West Africa. Malaria journal, 13(1), 126. https://doi.org/10.1186/14752875-13-126,

Arnell, N. W., Cannell, M. G. R., Hulme, M. Kovats, R. S., Michell, J. F. B., Nicholls, R. J., Parry, M., Livermore, M. J., \& White, A. (2002). The consequences of CO2 stabilization for the impacts of climate change. Climatic Change, 53, 413-446. https://doi.org/10.1023/A:1015277014327.

Arora-Jonsson, S. (2011). Virtue and vulnerability: Discourses on women, gender and climate change. Global Environmental Change, 21(2), 744-751. https://doi.org/10.1016/j.gloenvcha.2011.01.005. 
Asravor, R. K. (2018). Livelihood diversification strategies to climate change among smallholder farmers in Northern Ghana. Journal of International Development, 30(8), 1318-1338. https://doi.org/10.1002/jid.3330.

Awange, J. L., Aluoch, J., Ogallo, L. A., Omulo, M., \& Omondi, P. (2007). Frequency and severity of drought in the Lake Victoria region (Kenya) and its effects on food security. Climate Research, 33(2), 135-142. https://doi.org/10.3354/cr033135.

Beegle, K., \& Christiaensen, L. (Eds.). (2019). Accelerating poverty reduction in Africa. The World Bank. https://doi.org/10.1596/978-1-4648-1232-3.

Belay, A., Recha, J. W., Woldeamanuel, T., \& Morton, J. F. (2017). Smallholder farmers' adaptation to climate change and determinants of their adaptation decisions in the Central Rift Valley of Ethiopia. Agriculture \& Food Security, 6(1), 24. https://doi.org/10.1186/s40066-017-0100-1.

Berman, R. J.; Quinn, C. H. and Paavola. J. (2015). Identifying drivers of household coping strategies to multiple climatic hazards in Western Uganda: implications for adapting to future climate change. Climate and Development 7, no. 1, 71-84. http://doi.org/10.1080/17565529.2014.902355

Boko, M., Niang, I., Nyong, A., Vogel, A., Githeko, A., Medany, M., \& Yanda, P. Z. (2018). Africa Climate Change 2007: Impacts, Adaptation and Vulnerability: Contribution of Working Group II to the Fourth Assessment Report of the Intergovernmental Panel on Climate Change. Retrieved from http://hdl.handle.net/123456789/9455

Brocklesby, M. A; and Fisher, E. (2003). Community development in sustainable livelihoods approaches-an introduction." Community development journal38, no. 3, 185-198. doi.org/10.1093/cdj/38.3.185.

Burney, J., Cesano, D., Russell, J., La Rovere, E. L., Corral, T., Coelho, N. S., \& Santos, L. (2014). Climate change adaptation strategies for smallholder farmers in the Brazilian Sertão. Climatic Change, 126(1), 45-59. https://doi.org/10.1007/s10584-014-1186-0

Chambers, R. and Conway, G. (1992) Sustainable Rural Livelihoods: Practical Concepts for the 21st Century, IDS Discussion Paper 296, Brighton: IDS

Change, Intergovernmental Panel on Climate. (2007). Climate change 2007: The physical science basis. Agenda 6, no. 07: 333.

Cochrane P. (2006) Exploring cultural capital and its importance in sustainable development Ecological Economics,57(2006), pp.318-330 
The Perception of Rural Households on Climate Change Effect on Rural Livelihoods in Lake Victoria Basin

Cooper, P. J. M.; Dimes, J.; Rao, K. P. C.; Shapiro, B.; Shiferaw, B.; and Twomlow, S. (2008). Coping better with current climatic variability in the rain-fed farming systems of sub-Saharan Africa: An essential first step in adapting to future climate change? Agriculture, ecosystems \& environment 126, no. 1-2: 24-35. https://doi.org/10.1016/j.agee.2008.01.007

Deressa, T. T., Hassan, R. M., \& Ringler, C. (2011). Perception of and adaptation to climate change by farmers in the Nile basin of Ethiopia. The Journal of Agricultural Science, 149(1), 23-31. https://doi.org/10.1017/S0021859610000687F

DFID (2000). Sustainable Livelihoods Approach and its Framework. Retrieved from http://www.glopp.ch/B7/en/multimedia/B7_1_pdf2.pdf (Accessed on September 15 ${ }^{\text {th }}$ 2019)

Eastin, J. (2018). Climate change and gender equality in developing states. World Development, 107, 289-305. https://doi.org/10.1016/j.worlddev.2018.02.021

Eriksen, S., Aldunce, P., Bahipatp, C. S., Martins, R. D., Molefe, J., Nhemachena, C., O’brian, K., Olrunfem, F., Park, J., Sygna, L., \& Ulsrud, K. (2005). When not every response to climate change is a good one: Identifying principles for Sustainable adaptation. Climate and Development, 3, 711. https://doi.org/10.3763/cdev.2010.0060

Eriksen, S.; Aldunce, P.; Sekhar B. C.; 1 D'almeida M. R.; Molefe J. I.; Nhemachena, C.; O'brien, K.; Olorunfemi, F.; Park, J.; Sygna, L. \& Ulsrud, K. (2001). When Not Every Response to Climate Change Is A Good One: Identifying Principles for Sustainable Adaptation, Climate and Development, 3:1, 7-20, https://doi.org/10.3763/Cdev.2010.0060

Fankhauser, S and Richard S.J.T. (1997). The social costs of climate change: the IPCC second assessment report and beyond. Mitigation and adaptation strategies for global change 1, no. 4: 385-403. Retrieved from https://link.springer.com/content/pdf/10.1023/B:MITI.0000027387.05917.ae.pdf ( accessed May 2020).

FAO, Food. Agriculture Organization (2009). The state of food insecurity in the world 2008.

FAO, WFP and IFAD. (2010). The state of food insecurity in the world 2010: addressing food insecurity in protracted crises.

Farrington, J; Carney, D; Ashley, C. and Turton C. (1999). Sustainable livelihoods in practice: early applications of concepts in rural areas. Vol. 42. London. Retrieved from http://hdl.handle.net/10535/4235 (Accessed on September $11^{\text {th }}$ 2019)

Ferrol-Schulte, D; Matthias W; Sebastian F; and Glaser, M. (2013). Sustainable Livelihoods Approach in tropical coastal and marine social-ecological systems: A review." Marine policy 42, 253-258. doi.org/10.1016/j.marpol.2013.03.007 (Accessed December 2019 
Field, C. B.; Barros, V. R.; Mastrandrea, M. D.; Mach, K. J.; Abdrabo, MA-K., Adger, N.; Anokhin Y A. et al. 2014). Summary for policymakers." In Climate change 2014: impacts, adaptation, and vulnerability. Part A: global and sectoral aspects. Contribution of Working Group II to the Fifth Assessment Report of the Intergovernmental Panel on Climate Change. Cambridge University Press, 1142-1164,

Food and Agriculture Organization (FAO). (2009). State of food insecurity 2009. FAO: Rome.

Friedman, R., Hirons, M. A., \& Boyd, E. (2019). Vulnerability of Ghanaian women cocoa farmers to climate change: a typology. Climate and Development,11(5), 446-458. https://doi.org/10.1080/17565529.2018.1442806

Gebrechorkos, S. H., Hülsmann, S., \& Bernhofer, C. (2019). Changes in temperature and precipitation extremes in Ethiopia, Kenya, and Tanzania. International Journal of Climatology,39(1), 18-30. https://doi.org/10.1002/joc.5777

Gee Nee, L., and Mansur, K. (2015). Understanding poverty and vulnerability by utilizing the sustainable livelihood approach: a comprehensive study among Rungus ethnic in Sabah, Malaysia. Malaysian Journal of Business and Economics (MJBE)

Government of Kenya. (2019). 2019 Kenya Population and Housing Census: Kenya Bureau of Statistics, Government Printers, Nairobi.

Herrera, E; Magaña, V. and Morett, S. (2018). Relationship between Precipitation extreme events and floods. Case study: Tulancingo, Hidalgo. Nova Scientia 10, no. 21, 191-206. https://doi.org/10.21640/ns. v10i21.1527

Hiscock, K.; and Tanaka, Y. (2006). Potential impacts of climate change on groundwater resources: From the high plains of the US to the flatlands of the UK." In National Hydrology Seminar, vol. 2006, 19-25.

Hope, S \& Kempe R. (2009). Climate change and poverty in Africa. International Journal of Sustainable Development \& World Ecology 16, no. 6, 451-461. https://doi.org/10.1080/13504500903354424

Jarawura, F. X. (2014). Perceptions of drought among rural farmers in the Savelugu district in the northern Savannah of Ghana. Ghana Journal of Geography,6, 102-120. Retrieved from https://www.ajol.info/index.php/gjg/article/view/111137 on September 25, 2020.

Kendall, R. L. (1969). An ecological history of the Lake Victoria basin. Ecological Monographs39, no. 2, 121-176. https://doi.org/10.2307/1950740 
The Perception of Rural Households on Climate Change Effect on Rural Livelihoods in Lake Victoria Basin

Khisa, G. V.; Oteng'I, S. B.; and Mikalitsa, S. M. (2014) Effect of climate change on small scale agricultural production and food security in Kitui district, Kenya, http://hdl.handle.net/123456789/947 (Accessed December 2019).

Khisa, G. V.; Oteng'I, S. B.; and Mikalitsa, S. M. (2014). Effect of climate change on small scale agricultural production and food security in Kitui district, Kenya, http://hdl.handle.net/123456789/947 (Accessed December 2019).

King, C. C. (2012). Assessing the impact of microfinance programs by evaluating changes in income and capital scales. Saint Louis University.

Kristjanson, P., Bryan, E., Bernier, Q., Twyman, J., Meinzen-Dick, R., Kieran, C., \& Doss, C. (2017). Addressing gender in agricultural research for development in the face of a changing climate: where are we and where should we be going? International Journal of Agricultural Sustainability,15(5), 482-500. https://doi.org/10.1080/14735903.2017.1336411

Le Dang, H; Li, E; Bruwer, J. and Nuberg I. (2014). Farmers' perceptions of climate variability and barriers to adaptation: lessons learned from an exploratory study in Vietnam. Mitigation and adaptation strategies for global change 19, no. 5, 531-548. https://doi.org/10.1007/s11027-0139452-4

Liebmann, B., I., Bladé, G. N., Kiladis, L. M., Carvalho, G. B., Senay, D., Allured, S., Leroux, S \& Funk, C. (2012). Seasonality of African precipitation from 1996 to 2009, Journal of Climate, 25(12), 4304-4322. https://doi.org/10.1175/JCLI-D-11-00157.1

Mertz, O., Mbow, C., Reenberg, A., \& Diouf, A. (2009). Farmers' perceptions of climate change and agricultural adaptation strategies in rural Sahel. Environmental management,43(5), 804-816. https://doi.org/10.1007/s00267-008-9197-0

Mbilinyi, A; Ole Saibul, G. and Kazi, V. (2013). Impact of climate change to small scale farmers: Voices of farmers in village communities in Tanzania. Economic and Social Research Foundation, Dar es Salaam. 36, Available at http://esrf.or.tz/docs/Discussion Paper-47.pdf Accessed on June 4,2020

Mikalitsa, S.M. (2010). Gender-specific constraints affecting technology use and household food security in western province of Kenya. African Journal of Food, Agriculture, Nutrition and Development $\quad 10, \quad$ no. $4 . \quad$ Retrieved from https://www.ajol.info/index.php/ajfand/article/view/55327

Nabikolo, D., Bashaasha, B., Mangheni, M. N., \& Majaliwa, J. G. M. (2012). Determinants of climate change adaptation among male and female-headed farm households in eastern Uganda. African Crop Science Journal, 20(2), 203-212. Retrieved from https://www.ajol.info/index.php/acsj/article/view/81767 
Odero, K.K. (2008) Information capital: 6th asset of sustainable livelihood framework Discovery and Innovation, 18 (2008), pp. 83-91

Ogallo, L. J. (1988). Relationships between seasonal rainfall in East Africa and the Southern Oscillation. Journal of Climatology 8, no. 1, 31-43. https://doi.org/10.1002/joc.3370080104

Oluoko-Odingo, A. A. (2011). Vulnerability and adaptation to food insecurity and poverty in Kenya. Annals of the Association of American Geographers, 101, no. 1; 1-20. https://doi.org/10.1080/00045608.2010.532739

Paavola, J. (2008). Livelihoods, vulnerability and adaptation to climate change in Morogoro, Tanzania. Environmental Science \& Policy, 11(7), 642-654. https://doi.org/10.1016/j.envsci.2008.06.002

Panthi, J., Aryal, S., Dahal, P., Bhandari, P., Krakauer, N. Y., \& Pandey, V. P. (2016). Livelihood vulnerability approach to assessing climate change impacts on mixed agro-livestock smallholders around the Gandaki River Basin in Nepal. Regional Environmental Change, 16(4), 1121-1132. https://doi.org/10.1007/s10113-015-0833-y

Payne, J. T., Wood, A. W., Hamlet, A. F., Palmer, R. N., \& Lettenmaier, D. P. (2004). Mitigating the effects of climate change on the water resources of the Columbia River basin. Climatic Change, 62(1-3), 233-256. https://doi.org/10.1023/B:CLIM.0000013694.18154.d6

Poudel, S., Funakawa, S., \& Shinjo, H. (2017). Household perceptions about the impacts of climate change on food security in the mountainous region of Nepal. Sustainability, 9(4), 641. https://doi.org/10.1111/aje.12180

Quandt, A. (2018). Measuring livelihood resilience: The household livelihood resilience approach (HLRA). World Development107, 253-263. https://doi.org/10.1016/j.worlddev.2018.02.024

Reed, M. S., Podesta, G., Fazey, I., Geeson, N., Hessel, R., Hubacek, K., Letson, D., Nainggolan, D., Prell, C., Rickenbach, M. G., Ritsema, C., Schwilch, G., Stringer, L. C., \& Thomas, A. D. (2013). Combining analytical frameworks to assess livelihood vulnerability to climate change and analyse $\begin{array}{llll}\text { adaptation } & \text { options. } & \text { Ecological } & \text { Economics, }\end{array}$ https://doi.org/10.1016/j.ecolecon.2013.07.007

Reed, M. S., Podesta, G., Fazey, I., Geeson, N., Hessel, R., Hubacek, K., Letson, D., Nainggolan, D., Prell, C., Rickenbach, M. G., Ritsema, C., Schwilch, G., Stringer, L. C., \& Thomas, A. D. (2013). Combining analytical frameworks to assess livelihood vulnerability to climate change and analyse $\begin{array}{llll}\text { adaptation } & \text { options. } & \text { Ecological } & \text { Economics, }\end{array}$ https://doi.org/10.1016/j.ecolecon.2013.07.007 
The Perception of Rural Households on Climate Change Effect on Rural Livelihoods in Lake Victoria Basin

Sati, V. P; and Vangchhia, L. (2016). A sustainable livelihood approach to poverty reduction: an empirical analysis of Mizoram, the eastern extension of the Himalaya. 71-97, Springer. https://doi.org/10.1007/978-3-319-45623-2

Scoones, I. (1998) Sustainable rural livelihoods: a framework for analysis. IDS Working Paper 72. Retrieved from https://opendocs.ids.ac.uk/opendocs/handle/20.500.12413/3390

Scoones, I. (2015). Sustainable livelihoods and rural development (Agrarian change and peasant studies 4). Bourton on Dunnesmore, Rugby: Practical Action Publishing,

Shepardson, D. P., Niyogi, D., Roychoudhury, A., \& Hirsch, A. (2012). Conceptualizing climate change in the context of a climate system: Implications for climate and environmental education. Environmental Education Research, 323-352. https://doi.org/10.1080/13504622.2011.622839

Simotwo, H. K., Mikalitsa, S. M., \& Wambua, B. N. (2018). Climate change adaptive capacity and smallholder farming in Trans-Mara East sub-County, Kenya. Geoenvironmental Disasters, 5(1), 1-14. https://doi.org/10.1186/s40677-018-0096-2

Solesbury, W. (2003). Sustainable livelihoods: A case study of the evolution of DFID policy. London: Overseas Development Institute, Available file://C:/Users/user/Downloads/SustainableLivelihoods.pdf (Accessed on June 25,2020)

Spence, A., Poortinga, W., Butler, C., \& Pidgeon, N. F. (2011). Perceptions of climate change and willingness to save energy related to flood experience. Nature climate change, 1(1), 46-49. https://doi.org/10.1038/nclimate1059

Tanner, T., Lewis, D., Wrathall, D., Bronen, R., Cradock-Henry, N., Huq, S., Lawless, C., Nawrotzki, R., Prasad, V., Rahman, M. A., Alaniz, R., King, K., McNamara, K., Nadiruzzaman, M., HenlyShepard, S., \& Thomalla, F. (2015). Livelihood resilience in the face of climate change. Nature Climate Change, 5(1), 23-26. https://doi.org/10.1038/nclimate2431.

Teye, J. K., Yaro, J. A., \& Bawakyillenuo, S. (2015). Local farmers' experiences and perceptions of climate change in the Northern Savannah zone of Ghana. International Journal of Climate Change Strategies and Management. https://doi.org/10.1108/IJCCSM-05-2014-0066.

Thompson, H. E., Berrang-Ford, L., \& Ford, J. D. (2010). Climate change and food security in subSaharan Africa: A systematic literature review. Sustainability, 2(8), 2719-2733, https://doi.org/10.3390/su2082719.

Tucker, J., Daoud, M., Oates, N., Few, R., Conway, D., Mtisi, S., \& Matheson, S. (2015). Social vulnerability in three high-poverty climate change hot spots: What does the climate change literature tell us? Regional Environmental Change, 15(5), 783-800. https://doi.org/10.1007/s10113-014-0741-6. 
United Nations Environmental Programme (2002). Lake Victoria Basin Environment Outlook: Environment and Development, UNEP, Nairobi

Wabwire. E. O., Mukhovi, S.N. and Nyandega, I.A. (2020). The Spatial and Temporal Characteristics of Rainfall over the Lake Victoria Basin of Kenya in 1987-2016. Atmospheric and Climate Sciences, 10, 240-257. https://doi.org/10.4236/acs.2020.102013

Warner, K., \& Van der Geest, K. (2013). Loss and damage from climate change: Local-level evidence from nine vulnerable countries. Int. J. Global Warming, 5(4), 367-386. https://doi.org/10.1504/IJGW.2013.057289

Weber, E. U. (2010). What shapes perceptions of climate change? Wiley Interdisciplinary Reviews: Climate Change, 1(3), 332-342. https://doi.org/10.1002/wcc.41

Xu, J., Grumbine, R. E., Shrestha, A., Eriksson, M., Yang, X., Wang, Y., \& Wilkes, A. (2009). The Melting Himalayas: Cascading Effects of Climate Change on Water, Biodiversity, and Livelihoods. Conservation Biology, 23(3), 520-530. https://doi.org/10.1111/j.15231739.2009.01237.x

Yaro, J. A. (2013). The perception of and adaptation to climate variability/change in Ghana by smallscale and commercial farmers. Regional Environmental Change,13(6), 1259-1272. https://doi.org/10.1007/s10113-013-0443-5

Yaro, J. A. (2004). Theorizing food insecurity: Building a livelihood vulnerability framework for researching food insecurity. Norsk Geografisk Tidsskrift - Norwegian Journal of Geography, 58(1), 23-37. https://doi.org/10.1080/00291950410004375 